\title{
Prospects for the Development of Innovative Economy in the Republic of Kazakhstan in the Context of Globalization
}

\author{
Sholpan R. Abzhalelova* \\ Kainar Academy \\ 184 Zhibek Zholy Str., Almaty, Republic of Kazakhstan
}

Received 07.09.2019, received in revised form 03.12.2019, accepted 09.12.2019

The article considers the main directions of the innovation policy of Kazakhstan at the present stage of development.

Keywords: national innovation system, industrial and innovative development, economy of the future, innovation and investment processes.

Research area: economics.

Citation: Abzhalelova, Sh.R. (2019). Prospects for the development of innovative economy in the Republic of Kazakhstan in the context of globalization. J. Sib. Fed. Univ. Humanit. Soc. Sci., 12(12), 2128-2136. DOI: 10.17516/1997-1370-0516.

Innovative economy, or knowledge-based economy, is gradually replacing industrial economy based primarily on the use of natural resources. The specificity of the postindustrial breakthrough of the Republic of Kazakhstan involves putting forward the task of ensuring the flexibility and adaptability of the economic system as a whole, the ability of its economic agents that are enterprises and organizations to quickly and adequately respond to the challenges of the time. All countries that have already solved many problems of increasing the efficiency of investments in the development of human "capital" had to find their own solutions. In Kazakhstan, economic growth must be sustainable and not achieved at all costs, but be accompanied by progressive structural changes and the development of human potential, ensuring a reduction in the gap with the most developed countries in the world. Serious structural changes are taking place, which weaken the country's dependence on the situation in the fuel and

(C) Siberian Federal University. All rights reserved

* Corresponding author E-mail address: abzhalel.2004_1979@mail.ru ORCID: 0000-0002-2188-6280

This work is licensed under a Creative Commons Attribution-NonCommercial 4.0 International License (CC BY-NC 4.0). 
energy complex. It is this task that is central in the developed Strategic Plan for the Development of the Republic of Kazakhstan until 2020.

In the official regulatory documents of Kazakhstan, the concept of "innovation" began to be used 10-15 years ago; it was enshrined in the Law of the Republic of Kazakhstan "On Innovative Activities" and is defined as the result of innovative activities that have been implemented in the form of new or improved products (work, services), a new or improved technological process, as well as organizational, technical, financial, economic and other solutions in various areas of public relations, providing progressive influence on the different areas of production and social control spheres. I. Schumpeter interprets innovation as a new scientific and organizational combination of production factors, motivated by the entrepreneurial spirit (Botenovskaya, 2015).

Industrial and innovative development of the economy is one of the highest priorities of the state policy of the Republic of Kazakhstan. The government of the republic, using the favourable conditions for the country on the world energy market, sets the task of transferring the Kazakhstan economy to an industrial-innovative development model. The innovative scenario involves using competitive advantages in the fuel and raw materials sector to diversify and qualitatively update the economy. Such a development means the development and implementation of mechanisms for the fastest possible transformation of new knowledge into high technology and their integration into the main areas of society.

In the modern economy based on market relations, the successful creation of an entrepreneurial activity requires the creation of an innovative structure that is reflected at all stages of the innovation life cycle. At this stage of market development, a clear classification of all groups of participants in innovation activity with the separation of their functions is important.

Today, innovations are considered much more broadly, including not only the result of scientific and technological activity, which has been realized in the form of new or improved products, or technology that has qualitative advantages over the analogues used, but also social processes that suggest the relationship between economic entities and their environment. From this point of view, innovation is a deliberate change in the economic system, including the process of introducing new and improved methods for organizing and managing human activities.

The government's initiative regarding the development of nano-technologies did not even have time to give proper results, although it was the development of this area that could and in the future should become the starting point for economic growth. Effective developments in the field of nano-technologies are designed not only to bring the 
economy to an innovative path of development and a qualitatively new level of production capabilities, but also to create new jobs, contribute to increased demand and an overall improvement in the quality of life. It is now necessary to do what they could not do in a favourable period. Diversification of production and reorientation to domestic demand are the most important problems, the solution of which will give an impetus to a new direction of the domestic economy (Poslanie Presidenta Respubliki Kazakhstan..., 2017).

Against the backdrop of the globalization of the world economy, Kazakhstan is facing with a number of objective problems, which include raw materials orientation, insignificant integration with the global economy, weak inter-industry and inter-regional economic integration within the country, low consumer demand for goods and services in the domestic market, underdeveloped production and social infrastructure, the general technical and technological backwardness of enterprises, the lack of an effective connection between science and production, low expenses for R\&D, management mismatch with the tasks of adapting the economy to globalization processes and the transition to a service, technological economy.

In orderto ensure sustainable development through diversification and modernization of the economy, creating conditions for the production of competitive products and export growth, Kazakhstan adopted a number of program documents, such as the Strategy for Industrial and Innovative Development of the Republic of Kazakhstan for 2003-2015, the Program for the Formation and Development of National Innovation System of the Republic of Kazakhstan for 2005-2015, the State Program for the Forced Industrial and Innovative Development of the Republic of Kazakhstan for 2010-2014, the Technological Program on the development of the Republic of Kazakhstan until 2015, etc. A legislative base for systemic reforms was created, financial institutions were formed, namely, JSC Investment Fund of Kazakhstan, JSC National Innovation Fund, Centre for Engineering and Transfer Technologies, State Insurance Company for Insurance of Export Loans, Investments, etc.

Thus, the strategy, shaping the state economic policy of Kazakhstan for the period up to 2015, was aimed at achieving sustainable development of the country by diversifying the sectors of the economy and moving away from the raw material development direction. The production of competitive and export-oriented goods, works and services in the manufacturing industry and the service sector is the main subject of the state industrial and innovation policy.

According to the Strategic Plan for the Development of the Republic of Kazakhstan until 2020, one of the priority areas of economic development is the transition from 
an extensive, raw-material development path to an industrial and innovative one. This transition is impossible without the development of a national innovation system(NIS). NIS is a system of interconnected institutions for the creation, storage, transfer of knowledge and technologies, which has an internal structure established by the state to influence the innovation process. NIS can also be defined as a set of interconnected organizations (structures) engaged in the production and commercialization of scientific knowledge and technologies within national borders. At the same time, NIS is a complex of institutions of a legal, financial and social nature, providing innovative processes and having strong national roots, traditions, political and cultural features (Botenovskaya, 2015).

Summarizing the above definitions, we can say that the NIS represents the institutional basis for the innovative development of the national economy, in the framework of which the necessary conditions for effective scientific, technical and innovative activities in the country are created.

Today, innovative activity at industrial enterprises of the country is still not at a high level. According to WEF (WorldEconomicForum), Kazakhstan ranks 66th in the world in terms of readiness to accept new technologies, and 70th in terms of innovation development; the overall rating of innovative potential decreased by $10 \%$. The Government of Kazakhstan has set the task to increase the share of innovatively active enterprises up to $10 \%$ by 2015 . Among the innovative products of industrial enterprises, the largest share of $80 \%$ is occupied by products newly introduced or subjected to significant technological changes, products that underwent improvement occupy $14.6 \%$ and other innovative products occupy $5.4 \%$. The main types of innovation of enterprises with completed innovations are the introduction of new technologies, equipment, materials (55.2\%), research (13.3\%), design and development (5.8\%), participation in scientific and technical programs $(4.1 \%)$.

In total, 469 investment projects totalling more than $\$ 57$ billion are currently being implemented as part of the industrial and innovation program. To date, innovation support and development tools have been actively working in all regions of Kazakhstan. Thus, if in 2010 using all support tools, only 637 applications were collected from all regions and 133 of them were supported, in 2011 the number of applications collected amounted to 1231 applications, among which 500 projects were supported.

In the Kazakhstan innovation system, the proportion of higher education institutions doing research and development remains low. Private universities practically do not conduct scientific research, while state universities pay more attention to the educational function, rather than scientific one. 
One of the main directions of innovation policy is the creation of new high-tech industries to replace existing and inefficient ones. However, so far no results have been achieved in this direction. Despite the available scientific developments and projects, modern science in Kazakhstan is characterized by insufficiently qualified scientific personnel, a backward scientific and technical base, and bureaucratization of licensing and patenting processes. The result of the innovation policy of the state should be the production of competitive and export-oriented goods, works and services. The financial resources of the state should be invested in narrowly focused research, for the development and implementation of which there is sufficient scientific and industrial reserve (Vsemirnyi ekonomicheskii forum).

The analysis of indicators of innovative activity in the republic allows us to conclude that at the moment the national innovation system of Kazakhstan is in its infancy. Strong ties have not yet formed between its elements; often they exist in isolation from each other.

A significant drawback of the NIS model of Kazakhstan is the insufficiently active participation of business in research and development and, as a result, the low innovative activity of enterprises. The development of Kazakhstan's NIS takes place under conditions of unformed market relations and underdeveloped private capital, which could be used to develop and master the latest technology and technologies, as is the case in developed countries. The NIS should be based on the ongoing innovation policy and legislation of the Republic of Kazakhstan, taking into account the economic characteristics of the regions.

Within the framework of the adopted state program on accelerated industrial and innovative development of the Republic of Kazakhstan, the main instruments of innovation policy should be aimed at consolidating the efforts of business and the state in developing priority sectors of the economy, as well as in the formation of effective institutions and mechanisms for their interaction.

Today, Kazakhstan is undergoing radical transformations of its multistructural economy in order to increase the competitiveness of the country, where technological transformations such as overcoming technological degradation, mastering the technology of the modern fifth and future sixth technological structures, are of paramount importance. The tasks are currently set for the transition to an innovative type of economic development in Russia and in other countries and to an industrialinnovative one in Kazakhstan, in view of the not yet fully developed industrial sector of the economy and focus on a strategy to support high-tech production, the innovation 
sector and entrepreneurship. Kazakhstan is faced with the task of dynamically modernizing the entire system of socio-economic and socio-political relations. At the same time, the main focus is on the markets of Russia, China, Central Asia, the Caspian and Black Sea regions. This implies state support for the expansion of Kazakhstani capital, goods and services to foreign markets (Zhazylbek, 2017).

The tough competitive environment in the world market, the weak level of industry management, as well as the limited time frame for commercialization and unequal volumes and conditions of implementation have led venture capital funds of the country so far to invest in innovative technologies (Gosudarstvennaia programma po forsirovannomu..., 2010).

In addition, further improvement of the science management system is necessary in order to concentrate financial resources, human, scientific and technical potential in priority areas of science, and particularly to meet the needs of the effective development of the real sector of the country's economy, especially in those sectors where Kazakhstan has already had competitive results. It should be noted here that the rate of financial investments in R\&D should be compatible with the pace of development of human resources that can effectively use investments.

It is clear that the innovative economy for Kazakhstan is a way of responding to systemic constraints on the path of economic growth by creating, implementing and commercializing new technologies at all levels of decision-making. In modern conditions, only an innovative economy, based on borrowing, adapting to local conditions and developing the latest technologies, is able to raise the country's competitiveness, and hence the standard of living of the country's population to a fairly high level.

In the world, there is still no specific model for the innovative development of economy, strictly following which the country will surely come to socio-economic well-being. Kazakhstan must continue the reform process if it wants to reach a higher level of growth and development. Despite Kazakhstan's opportunities and innovative achievements in the form of sufficient venture capital, the ability of companies to innovate and increase the volume of public procurement of advanced technical products, due to the lack of effective developed tools in the field of law, technology and scientific personnel, it is difficult to characterize the general state of socio-economic development as innovatively directional (Zhazylbek, 2017).

Thus, the successful implementation of the innovation development strategy should contribute to the implementation of qualitative changes in the structure of the economy of Kazakhstan, which will lead to its sustainable growth based on the effective use of 
human, produced and natural capital, Kazakhstan's transition to a new level of social development and social structure. Thus, a macroeconomic policy of the Republic of Kazakhstan should be built basing on the current challenges of globalization and financial instability, increased competition in world markets, the increasing role of science and innovation, the development of human potential (Ospanov, 2009). For the benefit of the people of Kazakhstan, it is necessary to aim not at the ideals of individual and mass consumption, but at the preservation of family traditions and national characteristics of social relations. This is the main key to building a civil legal society in the Republic of Kazakhstan (Dzhelomanov, 2015). Today, Kazakhstan needs to look for new areas of economic development. To increase the country's competitiveness in the world market, it is necessary to actively develop high-tech industries and build an effective national innovation system on their basis.

\section{References}

Azbergenova, R.B. (2016). Zamedlenie ekonomicheskogo rosta v Kazakhstane i perspektivy ego preodoleniia $\mathrm{v}$ protsesse ego globalizatsii [Slowdown of economic growth in Kazakhstan and the prospects for overcoming it in the process of its globalization]. In Vestnik KazNPU im. Abaia. Seriia "Mezhdunarodnaia zhizn' i politika» [Bulletin of Abay KazNPU. International Life and Politics series], 2 (45).

Botenovskaya, E.S. (2015). Osobennosti innovatsionnogo razvitiia Evropeiskikh stran s maloi ekonomikoi [Features of innovative development of European countries with small economy]. In Novosti nauki i tekhnologii [News of science and technology], 1, 34-42.

Dzhelomanov, E.V.(2015). Innovatsionnaia aktivnost' cherezprizmu intellektual'noi sobstvennosti [Innovative activity through the prism of intellectual property]. In Nauka i innovatsii [Science and Innovation], 4, 51-53.

Gosudarstvennaia programma po forsirovannomu industrial'no-innovatsionnomu razvitiiu Republic Kazakhstan na 2010-2014 gody ot 19 marta 2010 goda № 958 [The state program for forced industrial and innovative development of the Republic of Kazakhstan for 2010-2014 dated March 19, 2010 \#958] (2010). Astana.

Internet resurs Tengrinews [Tengrinews Internet Resource]. Available at: www. tengrinews.kz/

Iskakov, U.M. (2012). Realii i perspektivy industrial'no-innovatsionnogo razvitiia Kazakhstana [Realities and prospects of industrial-innovative development of Kazakhstan]. In KazEUkhabarshysy [KazEU], 2, 41. 
Mukanova, A. (2010). Osnovnye tendentsii innovatsionnogo (nauchno-tekhnicheskogo) razvitiia Kazakhstana [The main trends of innovative (scientific and technical) development of Kazakhstan]. In Tranzitnaia Ekonomika [Transit economy], $5-6,42-47$.

Natsional'nye innovatsionnye sistemy v Rossii $i$ ES / Pod red. V.V. Ivanova $i d r$. [National Innovation Systems in Russia and the EU, ed. by V.V. Ivanov et al.] (2006). Moscow, Centre for Research on the Problems of the Development of Science of the Russian Academy of Sciences, 280 p.

Ospanov, B. (2009). Innovatsii kak napravlenie gosudarstvennoi strategii razvitiia v Respublike Kazakhstan [Innovation as a direction of the state development strategy in the Republic of Kazakhstan]. In Saiasat [Sayasat], 2, 17-21.

Poslanie Presidenta Respubliki Kazakhstan N. Nazarbaeva narodu Kazakhstana. 31 ianvaria 2017 g. "Tret'ia modernizatsiia Kazakhstana: global'naia konkurentosposobnost'» [Message from the President of the Republic of Kazakhstan N. Nazarbaev to the people of Kazakhstan. January 31, 2017 "The Third Modernization of Kazakhstan: Global Competitiveness"] (2017). Available at: www. akorda.kz/ru/

Programma po formirovaniiu i razvitiiu natsional'noi innovatsionnoi sistemy Republic Kazakhstan na 2005-2015 gody [The program for the formation and development of the national innovation system of the Republic of Kazakhstan for 2005-2015] (2005). Astana, 42 p.

Rakhman, A. (February 15). Novyi ekonomicheskii kurs Kazakhstana. Tsifry i fakty. Innovatsionnaia ekonomika [New economic course of Kazakhstan. Figures and facts. Innovative Economy]. In Kazakhstanskaia Pravda [Kazakhstan Pravda].

Sotsial'nye faktory novovvedenii v organizatsionnykh sistemakh [Social factors of innovation in organizational systems] (1980). Moscow, 185 p.

Vsemirnyi ekonomicheskii forum: Reiting global'noi konkurentosposobnosti 20152016 [World Economic Forum: Global Competitiveness Rating 2015-2016]. Centre for Humanitarian Technologies. Available at: gtmarket.ru/news/2015/09/30/7246

Zhazylbek, L.I. (2017). Perspektivy razvitiia innovatsionnoi deiatel'nosti v respublike Kazakhstan [Prospects for the development of innovative activity in the Republic of Kazakhstan]. In Vestnik KazNPU [Bulletin of KazNPU]. Available at: articlekz.com/article/18998 


\section{Перспективы развития инновационной экономики в Республике Казахстан в условиях глобализации}

Ш.Р. Абжалелова Академия Кайнар Республика Казахстан, Алматы, ул. Жибек жоль, 184

В статье рассмотрены основные направления инновационной политики Казахстана на современном этапе развития.

Ключевые слова: национальная инноваџионная система, индустриально-инновационное развитие, экономика будущего, инновационно-инвестиционные процессы.

Научная специиальность: 08.00.00 - экономические науки. 